\title{
Un cine impuro para salvar la Historia del Arte: algunas notas sobre el pensamiento de las imágenes del cine en Jacques Rancière y Didi-Huberman
}

Irene Valle Corpas

Universidad de Granada

irenevalle1991@gmail.com

RESUMEN: Jacques Rancière y Georges Didi-Huberman son buenos ejemplos de una reciente ola de pensamiento que desde la filosofía política y la antropología del arte, se sirven del cine para apelar a la potencia política de lo impuro en las creaciones artísticas, emparejada, con frecuencia, con la idea de resistencia al tiempo presente. Algunos procedimientos del cine de vanguardia y el cine moderno de los años sesenta, permiten generar un tercer espacio que nos sitúe más allá de ciertos principios rígidos de la Modernidad o de una Posmodernidad antivisual, desmaterializada y despolitizada (en sus versiones reducidas), así como de los modelos temporales que ambas proponen. Es por ello que analizaremos cómo la valoración del cine en la obra de Rancière y Didi-Huberman ha posibilitado un giro crítico y reflexivo en el pensamiento de las imágenes.

PALABRAS CLAVE: Cine moderno; Impureza; Jacques Rancière; Georges Didi-Huberman; Temporalidad heterogénea.

\section{An Impure Cinema to Save Art History: Some Notes on the Thinking of Cinema Images in Jacques Rancière and Didi-Huberman}

ABSTRACT: Jacques Rancière and Georges Didi-Huberman are good examples of a recent wave of thinking that, starting from political philosophy and the anthropology of art, use cinema to appeal to the political power of the impure in artistic creation, often paired with the idea of resistance to the present time. Some avant-garde and modern cinema procedures of the 1960s, allow us to create a third space that places us beyond certain rigid principles of Modernity or a dematerialized, antivisual and depoliticized Postmodernity (in its reduced versions), as well as the temporal models that both propose. This is why we will analyze how the appraisal of cinema in Rancière and Didi-Huberman has made possible a critical and reflexive turn in the thinking of images.

KEYWORDS: Modern Cinema; Impurity; Jacques Rancière; Georges Didi-Huberman; Heterogeneous Temporality.

Recibido: 21 diciembre de 2017 / Aceptado: 10 mayo de 2018.

\section{Introducción}

El objetivo de este texto es desarrollar varias líneas argumentativas que nos permitan entender por qué el cine -y en especial aquel que se ha venido llamando «cine moderno»- es tan importante en los actuales debates en torno a la potencia política de las imágenes y la necesidad de superar la dualidad moderno/posmoderno en el relato de la Historia del Arte. Para ello tomaremos como hilo la valoración que teóricos y filósofos han hecho de la impureza del cine, apoyándonos en las afirmaciones de algunos de sus mayores referentes -en este sentido Godard es quizá el artista que mejor nos puede servir y por ello lo tomaremos de ejemplo, pues ha condensado en su quehacer fílmico todas las tendencias y procedimientos que actualmente se han

Cómo citar este artículo: VALLE CORPAS, Irene, «Un cine impuro para salvar la Historia del Arte: algunas notas sobre el pensamiento de las imágenes del cine en Jacques Rancière y Didi-Huberman", Boletín de Arte-UMA, n. ${ }^{\circ}$ 39, Departamento de Historia del Arte, Universidad de Málaga, 2018, pp. 245-254, ISSN: 0211-8483, DOI: http:// dx.doi.org/10.24310/BoLArte.2018.v0i39.3749 
puesto en valor-, para, finalmente hacer un pequeño repaso por las posiciones que Jacques Rancière y Didi-Huberman han tomado respecto al cine y sus posibilidades políticas.

\section{La impureza del cine}

«Le cinéma est un art impur. Art impur parce que ses objectifs comme ses racines ne sauraient lui être propres» anota Jacques Aumont parafraseando a Godard (1999: 95). Ni por su material de partida, ni por sus mismos procedimientos, el cine no podía ser puro porque era el arte de la realidad en sus múltiples aristas, ante todo una relación, un movimiento constante entre dos puntos: «No hay imagen, sólo hay imágenes. $Y$ hay una cierta forma de articulación de las imágenes: desde el momento en que hay dos, tres... [...] Es el fundamento del cine (Godard en Bergala, 1998: 430). «El cine no existe en sí. Es un movimiento" (Godard en Aidelman, 2010: 60-61). Las imágenes no andan nunca solas e invitan a pensar en el movimiento que las lleva las unas hacia las otras, en mayor medida que en ellas mismas. Por su vocación antiesencialista y debido a esos espaciamientos o intersticios que quedan siempre entre las imágenes y que inevitablemente crean una distancia temporal, al cine se lo relacionaba con la impureza. Aunque en un sentido algo distinto, quizás con un cariz más marginalista, Pasolini, el otro gran adalid de lo espurio en aquellos años, tampoco se limitó a tomar cosas de otras artes sino que se arrojó hacia lo impuro como sustancia literaria, antropológica y sexual (es decir, política) en infinitos poemas, artículos y películas. A modo de pequeña muestra valgan unos versos tomados de una de sus Poesías inciviles: «Todos juran que son puros: / puros en la lengua...naturalmente: / señal de que el alma está sucia» (1997: 157). Las reservas que guardaba ante la idea de una pureza cinematográfica no eran menos tajantes: «Explicar el cine por el cine es inventar una pureza ficticia del arte por el arte -incluso de la industria por la industria- y crear así una oscura ontología» (Pasolini en Didi-Huberman, 2014b: 194). En mayor medida que las defensas de un cine impuro lanzadas por André Bazin (que no eran óbice para que el crítico promoviese tal ontología del cine de resonancias teológicas; véase Bazin, 1990), pareciera que Godard y Pasolini como tantos otros, tenían en mente aquella otra sentencia de Sartre:
El arte nunca ha estado de parte de los puristas [...] Es bien sabido que el arte puro y el arte huero son una y la misma cosa, y que el purismo estético era sencillamente una brillante maniobra defensiva de los burgueses del siglo pasado que preferían que los denunciasen como filisteos a que se descubriera que eran unos explotadores (Sartre, 1950: 56).

Visto así, el cine no tendría nada de lo que avergonzarse, al contrario, era el arte más popular de todos, siempre a medio camino entre la técnica y el divertimento de masas. Pero ahí no quedaba la cosa. Siguiendo el argumento de Sartre, el cine, si la ocasión lo requería, debía posicionarse políticamente, «mancharse las manos» y servir a una causa. Aunque con variaciones, durante años estas fueron las protestas que reivindicaba la palabra impuro: desde las posibilidades de establecer un contacto más estrecho con la realidad hasta la negativa a dejar el arte en manos de quienes tienen el alma sucia. Más allá de intereses filológicos, ¿qué otro sentido podría tener enredarse ahora en estas viejas disquisiciones? Son, a fin de cuentas, definiciones pensadas para los debates que recorrieron las décadas de los cincuenta y sesenta y ya fuesen más o menos existencialistas o humanistas, por lo demás fueron largamente meditadas y hasta zanjadas en su momento. Y sin embargo la palabra ha vuelto con fuerzas revividas. Las sentencias se repiten y recientemente Badiou sin ir más lejos, ha reiterado la necesidad de pensar el cine en tanto que «arte absolutamente impuro. Es el plus-un de las artes, parasitario e inconsistente» que trabaja con «el caos de lo impuro, [que] es también el caos del tiempo» (Badiou, 2009: 131; véase también Badiou, 2014: 36-39 y Badiou, 2004: 23-81). Un caos, se queja el francés, que permanece sin ser pensado: «en nuestros días ya no tenemos prácticamente ningún pensamiento del tiempo. [...] Hemos entrado en un período atemporal, instantáneo, lo cual muestra hasta qué punto, lejos de ser una experiencia individual compartida, el tiempo es una construcción e incluso, puede decirse, una construcción política» (2005: 137). Puede que cuando pronunció estas palabras acabara de salir de un cine donde se proyectaban Histoire(s) du cinéma, pues parecen robadas de su querido amigo Godard:

El totalitarismo del presente, tal y como se aplica mecánicamente cada día más opresor a nivel planetario. Esta tiranía sin 
rostro que los borra a todos en beneficio exclusivo de la organización sistemática del tiempo unificado del instante. A esta tiranía global y abstracta, desde mi punto de vista huidizo trato de oponerme. Porque yo intento, en mis composiciones mostrar una oreja que escuche el tiempo... En efecto, yo no puedo sino ser el enemigo de nuestro tiempo puesto que su tarea apunta precisamente a la abolición del tiempo y de ahí que yo no vea que en este estado una vida merezca ser vivida [La cursiva es nuestra] [1]

Los movimientos que idea la poética del cine son falsos movimientos, dice Badiou. ¿Y por qué no habría de jugar en nuestro favor, tal fundamento impuro del cine, fabulando con el tiempo más allá de ese presente totalitario en el que llevamos encerrados más de cuarenta años? ¿No tiene el cine capacidad para crear ficciones temporales que nos ayuden también a imaginar otras relaciones?

\section{La actual importancia política del cine}

Para algunos el cine es ese pensamiento político del tiempo que Badiou echa en falta, que ha sabido indicar pero no ha llegado a asumir en todas sus consecuencias ${ }^{2}$. Quizá porque es un consumado antiplatónico, Rancière sí ha querido hacerse cargo de esta posibilidad. Ha subrayado sin timidez la importancia del cine como fuerza impura y su carácter relacional al definirlo como una «multitud de cosas», como un conjunto de relaciones heterogéneas en manos del creador que las podría moldear para desarmar una determinada estructura del mundo. En esta empresa le acompaña Georges Didi-Huberman quien en mayor medida que ningún otro filósofo de los últimos años, ha tenido ojo para reconocer en el principio de impureza, la materia de base para edificar un original proyecto intelectual con el que pensar la Historia y sus imágenes (que se propone, como Godard, escuchar al tiempo y verlo en cada imagen) y que dice instalarse en el umbral entre estética y política: «La historia de las imágenes es una historia de objetos temporalmente impuros, complejos, sobredeterminados» (Didi-Huberman, 2001: 46). Así pues, la impureza del cine, pensada ahora en tiempos oscuros, resulta ser la piedra angular de las mejores aportaciones en el estudio de las imágenes y la teoría cultural que ha aparecido hará escasos años de la mano de la filosofía

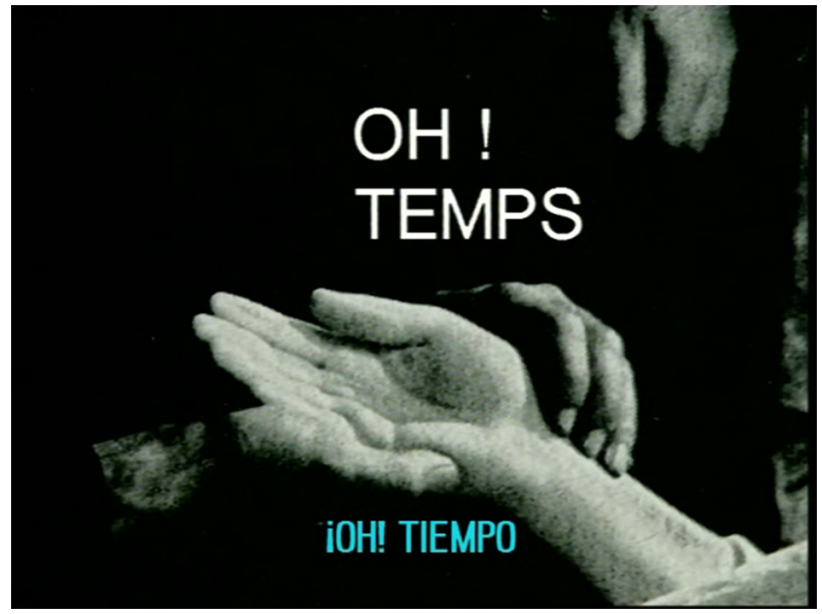

1. Fotograma de Histoire(s) du cinéma (Historia(s) del cine), Jean-Luc Godard, Francia, 1988

política y la antropología del arte y de unos renovados estudios visuales. Lo es incluso para aquellos que plantean una nueva institucionalidad del $\operatorname{arte}^{3}$. Se ha hablado de giro antropológico y político, pero poco importan los apelativos. Lo determinante es que se ha esbozado una posible política de las imágenes que hunde sus raíces en la tradición del cine crítico y experimental. Actualmente asistimos a una relectura por parte de estudiosos y artistas de ciertos procedimientos del cine en un arco que comprende los años 1920-1930 y posteriormente 1960-1980 al que habría que añadir las últimas creaciones del videoarte, aunque parece ser que el cine moderno de los sesenta es el que está siendo más estudiado, recuperado y citado. Pero es evidente que vistas - leídas ahora las obras de los sesenta que reivindican la impureza de lo estético, revisten un interés que responde a argumentos muy diversos a los que a la sazón se esgrimían en su defensa. $Y$ hace un par de párrafos que la pregunta parece obligada: ¿por qué ahora? O mejor dicho, ¿qué hay de crítico en nuestro momento actual para que sintamos tal necesidad? ${ }^{4}$ Digámoslo de un modo sencillo. Si en nuestra actual coyuntura se insiste en no hacer ascos a las junturas (y mucho menos a la del arte con la política) y se rebuscan respuestas en este cine crítico, en sus recursos y en sus nombres fundamentales, es por dos razones que caminan de la mano. En primer lugar porque ofrecen una impureza del tiempo y celebran la heterogeneidad y alteridad de la imagen así como la hibridez del espacio y de sus gentes, 
dando rostro a aquellos que eran invisibles hasta entonces. O lo que es lo mismo, el cine moderno, por su vocación etnográfica, política y poética lo pone todo en plural, desde ritmos temporales y lugares hasta pueblos, lenguas e historias, para hacer jaque a la uniformidad y mostrar la diferencia. A nuestros ojos esto es políticamente atractivo, pues en nuestro mundo el horizonte espacio-temporal ha ido estrechándose desenfrenadamente mientras las imágenes quedaban en manos de unos pocos, que las emplean para autorrepresentarse como sujetos sustanciales y únicos. Rastreando en dicha herencia del cine crítico muchos pensadores han encontrado una estética política de las imágenes que permita salir de la trampa en el que nos encontramos, esa celda sin salida de cuatro paredes: el tiempo vacío y circular, el espacio mercantilizado, la imagen-fetiche y la política secuestrada y reconvertida en gobernanza. Si las manos se manchan y si las imágenes toman posición es sobre todo al aceptar esta impureza y no por seguir un imperativo de militancia.

\section{Hacia una tercera vía. Cine, historia del arte e historia de las imágenes}

Esta trampa, no lo olvidemos, era también la trampa de la disciplina. Así, la vuelta de lo impuro ha inaugurado un nuevo capítulo en la historia del arte que pretende quitarse de encima algunos lastres. Uno de estos pesos muertos era aquel antiguo cuento de la historia del arte edificada sobre el relato vasariano o su actualización en el formalismo kantiano asentado con el Modernism, cuya lógica no hacía sino fortalecerse en los modelos antihistóricos que engendró cierta postura simplista de la Posmodernidad ${ }^{5}$. Librarse de ellos pasaba por pulverizar las fronteras entre las artes que decreta la ortodoxia moderna y convocar a la interdisciplinariedad (sin por ello caer en ninguna celebración fetichista), así como tejer otras narraciones basadas en una temporalidad distinta de la evolucionista o de la no menos cerrada esquizofrenia del presente perpetuo ${ }^{6}$. Tras las huellas de tal alternativa iban buscando los artistas más vanguardistas. Como ellos, el cine ya tenía los deberes hechos:

Y se comprueba entonces el derrumbe de esa modernidad en la década de 1960, bajo los golpes conjugados de la sos- pecha política acerca de la autonomía artística y la invasión de las formas comerciales y publicitarias. Esta historia de pureza modernista vencida por el todo vale posmoderno olvida que la confusión de las fronteras se puso en juego de manera más compleja en otros lugares, como el cine. (Rancière, 2012b: 11).

Como decimos, la invitación a dinamitar muros, tiene su correlato en una búsqueda de otra temporalidad. Y como anota Didi-Huberman en referencia al trabajo de James Coleman, esta debe trabajar en busca de «una experiencia del tiempo que no es reductible ni a la inmediatez de la aprehensión óptica (versión modernista) ni a la anomia de una memoria destinada a tomar acta de la obsolescencia de todas las cosas (versión postmodernista)» (Didi-Huberman, 2014a: 79). ¿Por qué habríamos de escoger de un modo tan binario? Ante tal disyuntiva los historiadores se dieron cuenta de que urgía generar un modelo nuevo que no se contentase ni con una visión reducida de la obra de arte como objeto autónomo, ni con aquella otra postura ultradesmaterializada que tomaba las imágenes como simulacros o mentiras absolutamente desligadas de un real en vías de extinción. Un tercer espacio que renunciase también a esa otra losa paralizante que censuraba tajantemente cualquier interferencia entre lo visual, lo textual y lo oral. Los historiadores del arte, críticos y estetas se veían obligados a tener que elegir entre un arte solo de la mirada estética (antifenomenológica, autoconsciente y estática) y un arte de la palabra igualmente volátil que rehúye lo visual al tomarlo exclusivamente por un perverso nido de relaciones de poder o insulsa excrecencia de nuestra sociedad de la abundancia. Desde los años setenta en adelante, una gran variedad de corrientes teóricas radicalizaron algunas perspectivas críticas a la visión apriorística y descorporeizada de la Modernidad llegando en ocasiones a una total demonización de lo visual ${ }^{7}$. Algunas eran derivaciones de la formulación sartriana de la reificación del sujeto mirado que luego Foucault recrudecería teorizando sobre el ojo del poder, unidireccional y sin rostro, panóptico y burocratizado ${ }^{8}$. Cuando no, se trataba de herencias de la censura situacionista a la borrachera de las imágenes que nos asaltan diariamente en nuestras espectacularizadas sociedades. Para los escépticos seguidores de Debord (o los adornianos, que para el caso sostienen posturas similares), las imágenes acumuladas hasta hacerse capital bloquearon 
nuestro imaginario, convirtieron la realidad en puro fetiche, en un universo de cartón piedra o una superficie brillante sin fondo alguno, y nos despojaron de la posibilidad siquiera de soñar con un contacto real con la cosas -ni que decir tiene que tal diagnóstico adquiere cada vez más peso dada la actual hipertrofia de la imagen multiplicada ya ad nauseam-. El cesarismo absoluto de la mirada y la seducción ilusionista de las imágenes: un crimen perfecto. Pareciera que si no se apostaba por una dialéctica de la mirada y una teoría de la imagen dialéctica, nos encontraríamos otra vez en paro técnico, otra vez ante dos imposibles juntos, uno al lado del otro, para negar una política de las imágenes. En la desencantada década de los ochenta, los inventores del «fin de la historia», llegaron con este nuevo y mejorado fin del poder de agencia de la mirada y de las imágenes para hablarnos de las cosas reales, para resistir activamente y servir a la emancipación social (¿cómo hacer algo así si son precisamente esas imágenes las que nos han sumido en la irrealidad más alienante?) ${ }^{9}$.

En su dilatada carrera Godard ha pasado por diversas posturas y corrientes. En los años sesenta estaba cerca de una fenomenología afín a las concepciones sobre la mirada de Merleau-Ponty y de la responsabilidad de la comprensión del mundo de Sartre que lo llevan a defender una determinada política de la visión. Igualmente tuvo ciertos coqueteos con ideas situacionistas acerca de la colonización de la vida cotidiana en el mundo moderno; hasta llegar a un cine abiertamente militante preocupado por denunciar la deformación perversa de la realidad que los medios de masas perpetraban diariamente y que pasaba por un ataque a las imágenes. Pero Godard, como sus compañeros de filas, fue siempre un maestro de la sospecha: «La imagen lo puede todo, lo mejor y lo peor»10, decía [2]. Exactamente igual que las palabras:

YI- Para usted las palabras son enemigas.

JLG- No, sólo cuando se toman las palabras como órdenes, sin pensamientos, o cuando se convierten en un cuchillo que se utiliza de forma inadecuada (Godard, 2000: 81).

Depende, claro está, de si somos capaces o no de rescatarlas del circuito de intercambio en el que el sistema capitalista las ha insertado para su venta y consumo. Su cine nos invita a pensar: ¿por qué razón absurda hemos de pensar que las imágenes y las palabras son enemigas entre sí

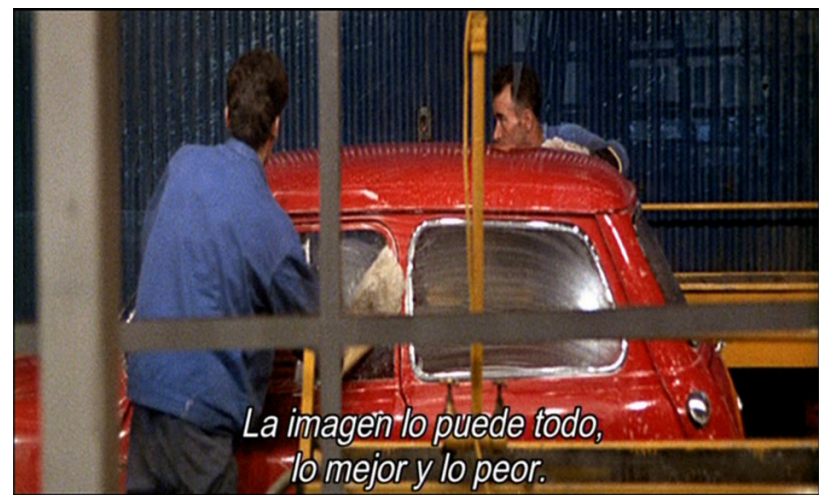

2. Fotograma de 2 ou 3 choses que je sais d'elle (Dos o tres cosas que yo sé de ella), Jean-Luc Godard, Francia, 1967

porque unas nos engañan y otras son nuestras aliadas en el conocimiento de la verdad? Las imágenes son tan certeras o tan embusteras como la escritura, no hay contraposición entre ellas. Ambas son significativas y el artista no debe temer que puedan chocar, tiene, al contrario, que jugar con esta posibilidad. Esta es la tarea que se propusieron los grandes cineastas de los años sesenta. Aprendieron a usar el inmenso archivo de las imágenes que acumuló el siglo y montarlas de otro modo, supieron emplear sus cámaras en la captación de un tiempo distinto al círculo huero del presente y una corporalidad resistente e hicieron que las imágenes volviesen a encender la llama política [3] y [4].

La historia del arte ha tardado algún tiempo en seguir los pasos de los creadores. Solo cuando lo ha logrado plenamente ha incluido el cine entre sus mayores intereses, pero para ello ha tenido primero que reconvertirse en historia de las imágenes ${ }^{11}$. Tal gesto tiene, nuevamente, un cariz político pues al prestar mayor atención al movimiento y a sus usos puede despertar las imágenes de la Historia y no arrinconarlas como objetos muertos y eternizados. La imagen es ahora, ella misma y el proceso (¿otra manera de hablar del tiempo?) que desencadena, ese acto de imaginación según Didi-Huberman, la reconfiguración de lo sensible que provoca en términos de Rancière y el acontecimiento que puede desatar para Badiou. En cualquiera de los casos a la obra se le reconoce el poder de romper el continuum temporal y el reparto espacial dado, así como se presta atención a las energías que posee para emplazar a una comunidad. 


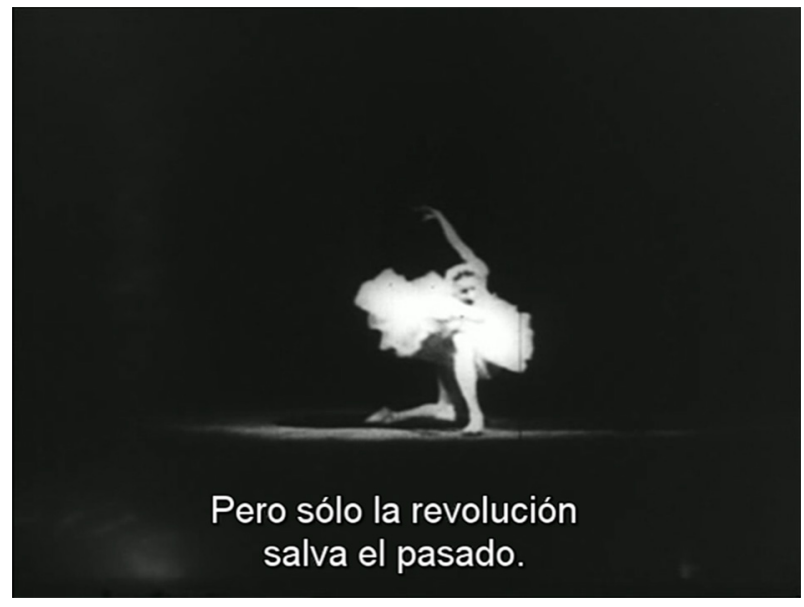

3. Fotograma de La Rabbia (La Rabia), Pier Paolo Pasolini, Italia, 1963. Empleado por Didi-Huberman en su libro Sentir le grisou, dedicado a este film

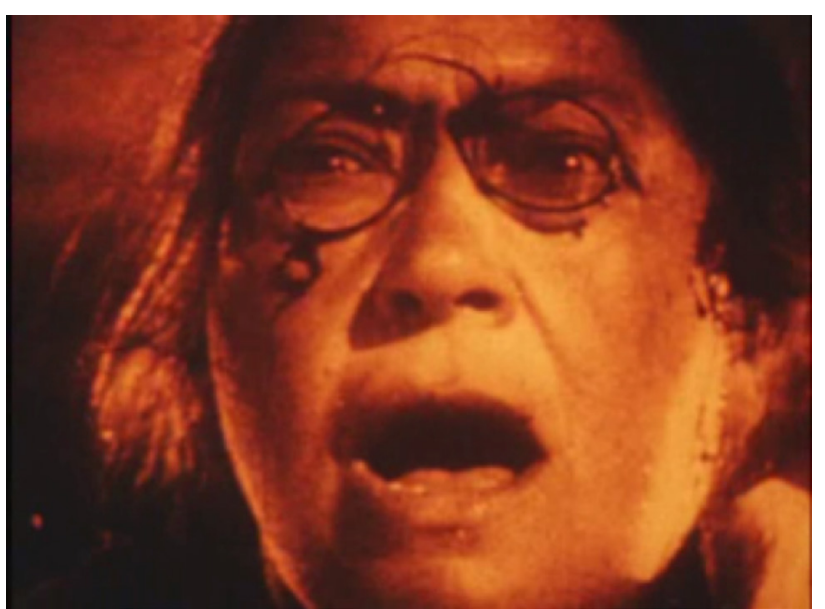

4. Fotograma de Le fond de l'air est rouge (El fondo del aire es rojo), Chris Marker, Francia, 1977. Esta imagen corresponde a un fotograma de Bronenósets Potiomkin (El acorazado Potemkin de Serguéi M. Eisenstein, 1925) que Marker incluye en su fresco sobre los movimientos políticos del ciclo 1967-1977. Esta doblez temporal es analizada en el catálogo de Soulèvements, reciente exposición de Didi-Huberman

\section{Cine y reparto de lo sensible. Jacques Rancière}

Esta es, por ejemplo, y no se cansa de repetirlo, la motivación última de Rancière (2007). No resulta extraño entonces que sus ensayos hayan vivido una segunda juventud en los primeros compases de nuestro siglo suscitando por igual el interés de artistas, activistas, politólogos o curadores. En su defensa de la experiencia estética como forma de producir una desviación en la experiencia ordinaria, Rancière mantiene una fe en el poder emancipador de las imágenes que en cierto sentido lo sitúa lejos de algunos de los teóricos de la filosofía francesa y en especial del Situacionismo. Su logro estriba en haber refutado de un solo golpe a los pensadores «realistas» y su pesimismo apocalíptico que en estos últimos años han desdeñado la existencia de la crítica en nuestro mundo consensual y mercantilizado, y sus hermanos gemelos posmodernos que tachan de simulacro toda imagen que se precie. Ambos se mueven en un callejón sin salida al hacer de toda protesta un espectáculo y de todo espectáculo una mercancía (Rancière, 2010a: 38). Si bien para Rancière aún estamos en condiciones de producir una distancia y el cine es una de sus mayores bazas. El filósofo francés defiende una alteridad de las imágenes del cine fundada en su capacidad para quebrar el paisaje de lo que «se ve y lo que se puede decir, de quien tiene competencia para ver y la cualidad para decir, sobre las propiedades de los espacios y los posibles del tiempo» (2014: 10). Y tal es, muy brevemente, su definición de la política como acto de interrupción que desbarata este juego de identidades a todas luces desigual por no hacer más que generar constantemente una exclusión, un residuo al que se le niega el derecho a tomar parte de lo común. Dicho así, la política es ella misma estética y poética por cuanto no es más que una configuración de lo sensible:

\begin{abstract}
Por su parte la política tiene su estética: en el fondo, la política es la constitución de una esfera específica de objetos supuestamente comunes y de sujetos supuestamente capaces de describir esa comunidad, de argumentar sobre ella y de decidir en su nombre. La acción política establece montajes de espacios, secuencias de tiempo, formas de visibilidad, modos de enunciación que constituyen lo real de la comunidad política. La comunidad política es una comunidad disensual (Rancière, 2005b: 55).
\end{abstract}

Arte y política son dos formas de división de lo sensible y cada una goza de sus propios mecanismos para ello. No hay tal conflicto entre la pureza y la politización, pues la estética y la política son dos modos de presencia de «cuerpos singulares en un espacio y un tiempo específico» (2012a: 36). El cine es muchas cosas, decía Rancière, y por ello rehúsa toda teoría unitaria. Pero, si hubiésemos de dar una 
definición esencial, diríamos con Rancière que el material con el que trabaja el cine no es más que ese sensible que debe ser desdibujado, desordenado, removido finalmente, en modos más igualitarios. Tal habilidad para abrir fisuras en la unidad de lo dado hasta dibujar una nueva topografía de lo sensible hace de cierto cine un arte del desacuerdo, político por derecho propio, más allá de las filias o fervores de militancia. Hemos de argumentar que Rancière elabora su teoría en los sesenta, cuando, según su criterio, hubo algunos filósofos y creadores que con una actitud poética hacia el arte y la política -las distinciones para el francés quedarían en buena medida anuladas por ser atributos de ese mismo arjé excluyente- «miraron el mundo que nos rodea de un modo diferente, volvieron visible lo imperceptible, sensible lo indiferente, volvieron extrañas cosas que caían por su propio peso» (2010b: 22). Por aquellos años el cine también pasa por una época dorada de hibridaciones, y cae en manos de videntes que lo pusieron al servicio de lo que hasta entonces había quedado invisible:

Durante los años 60, el éxito de la política de los autores coincidió con el gran momento de cuestionamiento del arte. Godard integró los dibujos animados pop o las performances en la transformación de lo continuo cinematográfico, provocando una transformación de la mirada del espectador. El cine tomó sus préstamos del tumulto de las vanguardias o de las exigencias políticas para constituirse en un arte que preserva su identidad incluso a través de la revolución de sus modos de descripción y narración (Rancière, 2005c).

El cine puede cortar o estirar el tiempo, superponer temporalidades heterogéneas a través del montaje o los planos ralentizados que alteren el totalitarismo del tiempo perpetuamente igual de la mercancía; tiene la capacidad, mediante la ficción y lo teatral, de imaginar cuerpos que recorren el espacio y lo viven de otro modo para privar al reparto de su carácter unívoco. De este modo el cine es el arte que abole todas las jerarquías sociales dando voz y mirada a través de la cámara a quienes carecen de ellas (por tomar un ejemplo, no otro propósito que el de hacer a los de abajo adueñarse de sus espacios y sus lenguajes, usando la cámara como medio de socialización, guía el cine militante que brotó en los alrededores de Mayo del 68, a uno y otro lado del Atlántico). Es el arte del desdén a las oposiciones entre documento o ficción, entre cuerpo y pensamiento o entre las especies artísticas y entre elementos visuales y textuales, es un entramado frases-imágenes, y textos, todo revuelto y escupido a la pantalla.

\section{Georges Didi-Huberman, una fenomenología política del cine}

En una carta dirigida al autor de La Mésentente, el propio Didi-Huberman reconocía la fraternidad de sus acercamientos: «a diferencia de toda una tradición de filosofía académica que no había visto en las imágenes del arte sino una posible guinda (estética) sobre el pastel del pensamiento (ontológico), usted se ha tomado en serio las imágenes en su inmanencia» (2017b: 127). Lo que no se habría tomado en serio, según Didi-Huberman y en este sentido sus reproches por haber despreciado la fenomenología son muy directos, es el propio material sensible al que apela la imagen: «la imagen reclama lo sensible, pero lo sensible implica el cuerpo, el cuerpo se agita con los gestos, los gestos vehiculan emociones, las emociones son inseparables del inconsciente, y el inconsciente implica en sí mismo un nudo de tiempos psíquicos, de manera que una sola imagen puede poner en juego o en cuestión todo el modelado del tiempo y de la historia misma incluso de la historia política» (2017b: 129). Puede que no haya habido una afirmación tan tajante del poder político del arte desde los años de la New Art History, aunque ahora el desplazamiento hacia lo visual y lo fílmico es ya más que evidente. Y Didi-Huberman no ha parado de repetirlo: «Las imágenes toman posición en cuanto tales, mejor dicho, en cuanto que se convierten en tales imágenes a través del montaje que les confiere esa eficacia que es tanto política (la posición como apertura de diferencias, si es que no de conflictos), como estructural (la posición como juego de lugares, si no de funciones)» (2017b: 125). No por otra razón, en su defensa de una fenomenología política de las imágenes, el francés ha dedicado un importante esfuerzo a completar un contra-modelo teórico para el estudio del cine que supere el impasse semiótico, siguiendo el curso marcado por Benjamin y Deleuze. Su acercamiento privilegia una visión antropológica del cine atenta a su materialidad y la de los cuerpos, gestos y emociones que muestra, a cómo conduce el deseo, así como se empeña en rastrear las tác- 
ticas políticas que puede desplegar el medio -algo que en el vocabulario del francés, insistimos, equivale a preguntarse por cómo juega el cine con el tempo-. Para ello se ha apoyado en la dialéctica de las imágenes en Warburg y en el marxismo heterodoxo de Benjamin que tanto alertó de los peligros del historicismo con su tiempo antimaterialista, "vacío y homogéneo", así como valoró en el trabajo de los surrealistas con lo maravilloso y las iluminaciones profanas (esas chispas que podrían prender un fuego liberador), la aparición de un modelo de desestabilización del presente a partir de la elaboración crítica del pasado. En lo que se refiere al cine, recientemente Didi-Huberman ha enriquecido su uso de la noción benjaminiana del tiempo-ahora, con la teoría deleuziana del montaje y la imagen-cristal, contenida en esencia en esta cita:

Lo que constituye a la imagen-cristal es la operación más fundamental del tiempo: como el pasado no se constituye después del presente que él ha sido sino al mismo tiempo, es preciso que el tiempo se desdoble a cada instante en presente y pasado [...] en dos direcciones heterogéneas, una que se lanza hacia el futuro y otra que cae en el pasado (Deleuze, 2015: 113-114).
Un acercamiento al cine que relegue tales impurezas del tiempo, o lo que es lo mismo, que olvide la memoria en toda su violencia -esa tradición de los oprimidos en la cual el tiempo adquiere su plenitud colectiva-, obstaculiza la posibilidad de una política de las imágenes, pues al fin y al cabo solo cuando logremos alcanzar una «mirada obrada por el tiempo", seremos capaces de desobedecer a la Historia homogénea del capitalismo tardío que ha hecho del tiempo un dispositivo de dominación ${ }^{12}$.

\section{Conclusiones}

En conclusión, creemos que es innegable que la filosofía de Rancière y Didi-Huberman ha producido un vuelco imposible ya de ignorar en la historia del arte, la historia del cine y el pensamiento sobre las imágenes desde las últimas tres décadas. Imágenes, por tanto, que nos sitúan ante lo real y ante la Historia sin perder de vista los mecanismos para revertirlos. Tal es, a su juicio, el potencial político que podemos aprovechar de este cine: aprender a lidiar con las paradojas de un tiempo en crisis y una cultura llena de contradicciones y tocada de un malestar no completamente incurable.

\section{Notas}

1 Un análisis de esta magna y melancólica obra godardiana que tiene en cuenta las teorías de Rancière y Didi-Huberman puede encontrarse en Ruiz, 2009. Acúdase especialmente al capítulo 9, «Memoria».

2 Rancière reprocha a su antiguo compañero que «la noción específica de impurificación aplicada al cine, es una manera de volver a las posiciones propias del pensamiento modernista», con lo que el cine, no sería un «verdadero arte» para Badiou y así tan pronto como elogia su impureza la niega (véase Rancière, 2012a: 79-110).

3 Véanse Expósito y Borja-Villel, 2015: 183-184 y Borja-Villel y Guerra, 2014. Acúdase también a las reflexiones de Hito Steyerl sobre las posibilidades del cine en el museo como medio que evidencia las carencias de la esfera pública burguesa y sus pretensiones de transparencia. (Steyerl, 2014: 63-79).

4 Tomamos la noción de «momento crítico» o «Ahora de lo conocible» de la lectura de Didi-Huberman del Lesbarkeit benjaminiano o lisibilidad de la historia. Véase Didi-Huberman, 2006. Tal principio lo fundamenta el historiador francés en su particular teoría del montaje: "Las imágenes se vuelven preciosas para el saber histórico a partir del momento en el que se ponen en perspectiva en unos montajes de inteligibilidad» (Didi-Huberman, 2011).

5 Por Modernism entendemos una tradición teórica elaborada en Norteamérica durante los años 30 y 60 principalmente por los críticos de arte Clement Greenberg y Michael Fried devenido discurso hegemónico en el contexto de la Guerra Fría y convertido en lo que Francis Frascina siguiendo a Noam Chomsky, denomina un "paradigma". Por su parte Rancière denomina «régimen estético del arte" a la división de la visibilidad e inteligibilidad del arte asociado a la autonomía del mismo, que no responde ya a valores representativos y éticos e indica que los discursos que estipula una única temporalidad para el arte o niegan sus contactos con las otras esferas de la experiencia colectiva no son más que negaciones del régimen estético del arte.

6 Por esquizofrenia nos referimos a un desorden enfermizo motivado por una pérdida de la experiencia de la continuidad temporal que nos lleva a vivir en la amnesia y el presente perpetuo. Con variaciones ha sido señalado por críticos como David Harvey, Andreas Huyssen Paul Virilio, o Frederic Jameson, siendo este último quizá el verdadero chef de file en esta cuestión, aunque evidentemente, todos ellos surgen del crucial Mil Mesetas: Capitalismo y Esquizofrenia de Felix Guattari y Gilles Deleuze. Y recientemente por Jonathan Crary y Marc Augé, entre otros. Que el tiempo es una cuestión crucial actualmente para todos los filósofos políticos puede intuirse acudiendo al último libro de Rancière (2018). Igualmente Didi-Huberman ha anunciado que dedicará su próximo seminario (2018-19) a la cuestión del tiempo y la subjetivación política.

7 Un repaso por las mismas, desde el psicoanálisis hasta el feminismo o el cine como «dispositivo» (noción esta última desarrollada por Jean-Luis Baudry), puede encontrarse en Stam, 2001: 191-211. 
8 Acerca de lo visible en Foucault como instrumento de poder que liquida una dialéctica fenomenológica de la mirada se ha pronunciado Jameson en (1995). Igualmente puede acudirse al estudio sobre el antiocularcentrismo en el pensamiento francés (Jay, 2007).

9 Nos encontramos así a Rancière discutiendo con Debord, y a Didi-Huberman en abierta refriega contra Gérard Wajcman y Claude Lanzmann, ambos para combatir a quienes deprecian la capacidad de la mirada para la emancipación o las posibilidades de las imágenes de establecer un contacto con lo real. Hasta Jean-Louis Comolli, crítico mayor del cine como aparato ideológico, esto es, como espectáculo, ha reconocido que es necesario ir más allá de Debord y luchar con los medios mismos del espectáculo para crear, a la manera de Rancière, un espectador emancipado. Véase Comolli, $2009:$ 7-14.

10 Quizá por el recelo que tuvo Godard ante el concepto de manipulación y alienación en sí por las imágenes, el cineasta sea tan recurrente para Rancière y Didi-Huberman. De la inmensa bibliografía de ambos, solo lo principal en relación con el exceso de las imágenes y la obra de Godard: (Rancière, 2008), (Rancière, 2005a) y (Rancière, 2011). Didi-Huberman tiene un monográfico dedicado al cineasta (Didi-Huberman, 2017).

11 Un ejemplo reciente de este vuelco nos lo ofrece (Hockney y Gyaford, 2017). En este ensayo llega a asegurarse: «La historia de las imágenes borra los límites habituales entre culturas elitistas y populares, entre imágenes fijas y animadas e incluso entre imágenes de buena y de mala calidad" (15).

12 Esta actitud hacia ese «archivo del siglo» que es el cine, ha llevado al filósofo francés a estudiar la obra de Sergei Eisenstein, Jean Vigo, Jean-Luc Godard, Pier Paolo Pasolini, Harun Farocki, Joris Ivens, Alain Resnais, James Coleman e incluso el aspecto más visual de la obra de Bertolt Brecht.

\section{Bibliografía}

AIDELMAN, Nuria y DE LUCAS, Gonzalo (eds.) (2010), Jean-Luc Godard. Pensar entre imágenes. Conversaciones, entrevistas, presentaciones y otros fragmentos, Intermedio, Barcelona.

AUMONT, Jacques (1999), Amnésies: Fictions du cinéma d'après Jean-Luc Godard, P.o.L, París.

BADIOU, Alain (2004), «El cine como experimentación filosófica» en YOEL, Gerardo (ed.), Pensar el cine 1: imagen, ética y filosofía, Manantial, Buenos Aires.

- (2005), El siglo, Manantial, Buenos Aires.

- (2009), Pequeño manual de inestética, Prometeo Libros, Buenos Aires.

- (2014), El cine como acontecimiento, Paradiso, Ciudad de México.

BAZIN, André ([1958-1963], 1990), «A favor de un cine impuro», ¿Qué es el cine?, Rialp, Madrid, pp. 101-129.

BERGALA, Alain (ed.) (1998), Jean-Luc Godard par Jean-Luc Godard, II: 1984-1998, Cahiers du cinéma, París.

BORJA-VILLEL, Manuel y GUERRA, Carles (2014), «El cine crítico como modelo de un nuevo museo». En: <https://www.youtube.com/ watch?v=1JKuuzOfbi0\&t=1439s> (fecha de consulta: 9-12-2017).

COMOLLI, Jean-Louis (2009), Cinéma contre spectacle, Verdier, París.

DELEUZE, Gilles (2015), La imagen-tiempo. Estudios sobre cine 2, Paidós, Barcelona.

DIDI-HUBERMAN, Georges (2001), Ante el tiempo. Historia del arte y anacronismo de las imágenes, Adriana Hidalgo, Buenos Aires.

- (2006), «Ouvrir les camps, fermer les yeux», Annales. Histoire, Sciences Sociales, n. 61, pp. 1011-1049.

- (2011), Imágenes pese a todo. Memoria visual del Holocausto, Paidós, Barcelona.

- (2014a), Essayer voir, Minuit, París.

- (2014b), Pueblos expuestos, pueblos figurantes, Manantial, Buenos Aires.

- (2017), Pasados citados por Jean-Luc Godard, Shangrila Textos Aparte, Santander.

- (2017b), «Imagen, lenguaje: la otra dialéctica», en CABELLO, Gabriel, LESMES, Daniel y MASSÓ, Jordi (eds.), Anthropos. Cuadernos de cultura crítica y conocimiento. Georges Didi-Huberman. Imágenes, historia, pensamiento, n. 246.

EXPÓSITO, Marcelo y BORJA-VILLEL, Manuel (2015), Conversaciones con Manuel Borja-Villel, Turpial, Madrid.

GODARD, Jean-Luc e ISHAGHPOUR, Youssef (2000), Archéologie du cinéma et mémoire du siècle, Farrago, Tours.

HOCKNEY, David y GAYFORD, Martin (2017), Une histoire des images: de la grotte à l'écran d'ordinateur, Solar éditions, París.

JAMESON, Fedric (1995), El posmodernismo y lo visual, Colección Eutopías, Episteme, Valencia.

JAY, Martin (2007), Ojos abatidos. La denigración de la visión en el pensamiento francés del siglo XX, Akal, Madrid.

PASOLINI, Pier Paolo (1997), La religión de mi tiempo, Icaria, Barcelona.

RANCIĖRE, Jacques (2005a), La fábula cinematográfica. Reflexiones sobre la ficción en el cine, Paidós lbérica, Barcelona.

- (2005b), Sobre políticas estéticas, Museu d'Art Contemporani de Barcelona, Barcelona.

— «El destino del cine como arte», Zinema. En: http://www.zinema.com/textos/eldestin.htm (fecha de consulta: 9-12-2017). 
RANCIÈRE, Jacques (2007), En los bordes de lo político, en https://desidentificacion.files.wordpress.com/2017/02/rancic3a8re-en-los-bordes-de-lo-politico.pdf

- (2010a), El espectador emancipado, Manantial, Buenos Aires.

- (2010b), Momentos políticos, Clave Intelectual, Buenos Aires.

- (2011), El destino de las imágenes, Prometeo Libros, Buenos Aires.

- (2012a), El malestar en la Estética, Clave Libros, Buenos Aires.

- (2012b), Las distancias del cine, Manantial, Buenos Aires.

- (2014), El reparto de lo sensible: estética y política, Prometeo Libros, Buenos Aires.

- (2018), Les temps modernes. Art, temps, politique, La Fabrique, París.

RUIZ, Nuria (2009), En busca del cine perdido. Histoire(s) du cinéma de Jean-Luc Godard, UPV, Vicaya.

SARTRE, Jean-Paul (1950), ¿Qué es la literatura?, Losada, Buenos Aires.

STAM, Robert (2001), Teorías del cine. Una introducción, Paidós, Barcelona.

STEYERL, Hito (2014), Los condenados de la pantalla, Caja Negra, Buenos Aires. 